\title{
Disrupting Contemporary Child Slavery Through Organization Networks: The Possibilities and Barriers
}

\author{
Lynette Shultz (University of Alberta)
}

\begin{abstract}
Increases in slavery have been identified in most countries in the world and are understood to be a global problem with local patterns and consequences. Education organizations, including schools, teacher organizations, as well as non-formal education organizations, have the potential to function as powerful partners in preventing and eliminating child slavery through the provision of quality education and also as locations of information sharing and action coordination. This study examines existing organization, inter-organization and organization-institution networked relationships to understand if and how education organizations have taken up an active role as sites to disrupt contemporary child slavery or to rehabilitate children removed from slavery. The study reveals four key barriers to successful utilization of education providers and provides new understandings of how to more effectively address the ever more expansive and violent practice of child slavery.
\end{abstract}

\section{Résumé}

Le redoublement de l'esclavage a été identifié dans la plupart des pays du monde et reconnu comme un problème mondial avec des conséquences et caractéristiques locaux. Les organisations scolaires, comprenant les écoles, les organisations des enseignants ainsi que d'autres organisations scolaires non formelles, ont la possibilité de fonctionner comme des partenaires puissants dans la prévention et l'élimination de l'esclavage des enfants en procurant une éducation de qualité et en servant comme les lieux d'échange de renseignements et de coordination d'actions. Cette étude examine la relation entre les membres du réseau déjà établi des organisations, inter-organisations et des institutions pour savoir si et comment les organisations scolaires prennent un rôle actif comme des sites, luttant contre l'esclavage contemporain des enfants, ou servant de centres de réadaptation aux enfants sauvés de l'esclavage. Cette étude montre les quatre barrières clés qui interdisent le succès du service des pourvoyeurs d'éducation et propose de nouvelles compréhensions pour montrer une voie plus efficace dans la lutte contre la pratique expansive et violente de l'esclavage des enfants.

\section{Introduction}

The reality that an increasing number of the world's children exist in conditions of slavery is one that receives unanimous condemnation. While one might expect absolute outrage and immediate action by the international community, national and regional governments and local communities, it is clear that the number of child slaves continues to increase while progress on institutional actions are relatively slow. Education organizations, including schools, teacher 
preparation programs, teacher associations and non-formal programs, have the potential to function as powerful partners in preventing and eliminating child slavery through the provision of quality education and also as locations of information sharing and action coordination. Participants in this study unanimously spoke of the need for collaborative efforts and network building if there is to be any real change in the lives of children who have been enslaved or any prevention for those children who are vulnerable to being enslaved. This paper explores if and how that is happening and identifies the gaps that prevent collaborative efforts. Points of tension between organizations and the institutional field are also highlighted as barriers to effective collaborative work.

\section{$21^{\text {st }}$ Century Slavery}

To understand the role of education in providing both vulnerable children the information necessary to avoid becoming enslaved and former child slaves a way to reintegrate into society as engaged citizens, it is important to explore the experience of slavery in its contemporary form. Slavery is often considered a practice that had been eliminated, however, it is currently increasing in most parts of the world, with an estimated twenty-seven million people currently held in slavery conditions (Bales, 1999). Slavery can be defined as the total control of one person by another for the purpose of economic exploitation. This control involves the sale and purchase of humans, often brutal psychological and physical violence, and exploitation for economic gains (Bales, 1999; 2000). Slavery is closely related, in experience and in efforts to understand and eliminate it, to human trafficking. Slavery is often at the end of the human traffic experience where people are taken from their communities, through force, coercion, and deception. "Trafficking occurs when persons are transported, in a context of exploitation, from a place of origin to a final point or destination. In some cases the destination may be far from the place of origin" (Unicef, 2003, p. 10). In a major study on human trafficking, UNICEF describes the complexity of the links within the trafficking process: "In South Africa, for example a number of children trafficked from Lesotho were found to be Mozambique nationals. In Tanzania children from refugee camps housing Burundian children were trafficked internally to work in tobacco plantations”( p. 18).

Persons migrating legally from one country to another find themselves at risk because of poverty, discrimination and marginalization and become trapped in a trafficking network. Persons trafficked from one country to another for a particular purpose are later trafficked to a third country, for a different purpose. For example, a child may be trafficked the first time as a domestic worker, and trafficked later on as a woman, sold or recruited into prostitution. Persons trafficked internally, from a rural area to an urban area, and later trafficked to another country for a different purpose. This creates a link between internal and cross-border trafficking. (Unicef, 2003, p. 18-19)

Although exact figures are very difficult to determine because of the underground nature of slavery and trafficking, all reports indicate the number of 
slaves continues to increase. Early work by Dr. Kevin Bales and nongovernmental organizations (NGO) such as Anti-Slavery International presented important information about slavery in its contemporary (Bales, 1999; 2000). This work described a new trend in which enslaved people were "disposable" because of an abundant supply, a cheap price and lack of involvement of the legal system (Bales, 1999, p. 118). The United Nations Department of Economic and Social Affairs (UNDESA) estimates "each year 700000 people are trafficked for the purpose of sexual exploitation and forced labour” (2002, p.1) and the US State Department (2003) estimates between 800000 and 900000 people are trafficked across borders each year. They also estimate 45000 to 50 000 women and children are trafficked into the US annually (Ibid). UNICEF (2003) produced a report based on extensive field research and estimated that 1.2 million children are trafficked each year. End Child Prostitution and Trafficking UK (ECPAT) (2004) provide evidence that child trafficking is for the purposes of prostitution, domestic servitude and other forms of labour exploitation. Bales, Fletcher \& Stover, (2004) released a report that indicates there have been reported cases of slavery in 90 US cities in the past 5 years. They also conclude that slavery is "prevalent in 5 sectors of the US economy: sex service (46\%), domestic services (27\%), agriculture (10\%), sweatshop/factory (5\%), and restaurant \& hotel work (4\%) (p. 5). Their research also concludes that "forced labour persists in these sectors because of low wages, lack of regulation and monitoring of working conditions, and a high demand for cheap labour” (p. 1).

The focus of most research at this time is on proving the existence and extent of slavery rather than on improving interventions and preventions which might disrupt the continuation of slavery. One NGO staff member lamented this fact in a recent interview:

We find, for the external players, we have to continuously provide evidence for why they [enslaved children] are described in this way. Whether it is in numbers, how many have been included, or evidence in definitional clarification; what constitutes this child as the worst forms of child labour? So its kind of [a focus on] evidential proving before we can talk about impact.(Interview, International NGO, 2005)

The impatience of this education professional to get on with dealing with a very real issue and focusing on having an impact on the problem is echoed throughout interactions with people working with these children. It was also clear that there where significant gaps in how and between whom information and knowledge was being exchanged.

Agencies have difficulty with two things, one, a child rights based approach and two, acknowledging the extent to which children are being abused. We need to have child rights champions that will stand up and say 'this is what is happening, and you need to address it no matter how uncomfortable it makes you. No matter what you feel'; it's not about charity but it is about children's rights in certain issues and

30 Canadian and International Education Vol. 35 no. 1 - June 2006 
certainly to protection. It is not a popular position to take. (Interview, International agency, 2005)

\section{The Study}

This study included fourteen organizations working in the area of education provision to children who have been rescued or removed from slavery or in prevention education programs. A chain referral process was used to identify respondents because it has been identified as an effective way to identify policy network members. (cf Farquharson, 2003; Atkinson \& Flint, 2001; Vogt, 1999). It is an effective form of link tracing methodology (Atkinson \& Flint, 2001) and an effective technique in finding research subjects who are difficult to find (Farquharson, 2003; Vogt, 1999). The chain referral process is also considered to be a practical method for studies that are explorative and qualitative (Farquharson, 2003; Atkinson \& Flint, 2001). Interviews are a data collection method used most often with this sampling process and as Van Meter (1990) suggests, it is a very effective way to "study up" from an issue to explore the context.

The organizations in the study included

(1) Formal school programs based in Sudan and India

(2) Community based organizations, providing non-formal education and policy work, based in India, Sudan and Canada

(3) International non-governmental organizations, supporting both formal and non-formal education and policy capacity building work, based in Canada, the United Kingdom and India

(4) International advocacy organizations, working with community groups on programming and internationally on policy change, based in the United Kingdom and India

(5) A regional coalition of organizations based in India

(6) Multilateral organizations including the International Labour Organization (ILO), International Programme on the Elimination of Child Labour (IPEC) and UNESCO

(7) International donor agencies based in Canada and the United Kingdom

Data was collected through semi-structured interviews, analysis of organizational documents and field observations. Interviews were carried out at organization offices and local education sites in Canada, the United Kingdom and India. The interviews were recorded and analyzed for emerging themes and patterns. Information from the interviews was triangulated with an analysis of organizational documents. Information was collected regarding the origin and development of the organization in terms of community context, exclusivity and inclusivity of the organization and relationships to other organizations, and institutional linkages including collective action and information exchange. In addition, ideational patterns in understandings of child slavery and child work, of appropriate interventions, of causal factors and possibilities for change were explored. Through this process it was made clear that there were significant barriers to organizational work in this area. These barriers form the basis of this 
paper. Future research work on how to mitigate, if not remove, these barriers would be an important way forward.

\section{What is a network?}

The United Nations Development Program (UNDP) (2000) defines a network as "a set of organizations or individuals that join in collaboration" (p. 6) and that become "ventures for social interaction through exchange and mutual learning” (p. 7). Church, Bitel, Armstrong \& Fernando (2002) emphasize the importance of a common purpose in the structure and functions of a network. They suggest "it is joint activity that gives edge and power" (p. 15) to a network. Davis (2003) in his work on networks and development interventions, suggests the

defining feature of network analysis is the focus on the structure of relationships between people (or whatever entity is of concern). This is contrasted with other areas of the social sciences where, it is claimed, the focus has been on attributes of actors, the characteristics of people, groups and organizations rather than the relations between them. (p. 4)

What purpose does involvement in a network serve?

At the macro-level, networks can be viewed as "valuable and useful development mechanisms to address emerging and multi-dimensional issues that requires contributions from a large number of actors” (UNDP, 2000, p.33). Networks, and organizations connected through networked relationships, have the "capacity for responsive adaptation in the face of variable local contexts" (p. 7). As social, economic, and political arrangements, networks can enhance capacity and promote collaboration amongst various groups towards the achievement of concrete goals (UNDP, 2000, p. 8).

Research by Church et al (2002), and UNDP (2000) identifies the benefits and advantages of networks, including "networks' capacity to engender dialogue across diverse groups, address global problems through global action locally rooted, reduce isolation, and increase potential for political and social action" (Church et al, 2000, p. 4).

In their study of "Participation, Relationships, and Dynamic Change", Church et al., (2002) examine international networks of organizations to study the "way relationships, trust, collaborative action, structure, participation and reflection inter-relate in the network form. Each connects to the other through a feedback loop, and each affects the other" (p. 1). The importance of these elements to development, including education, is captured in the conclusion drawn by Woolcock (1998) who states:

Development outcomes are shaped by the extent to which basic social dilemmas at the micro and macro level are resolved. Positive outcomes are attained to the extent that both embedded and autonomous social relations prevail at both levels. This happens when people are willing and able to draw on nurturing social ties i) within 
their communities; ii) between local communities and groups with external and more extensive social connections to civil society; iii) between civil society and macro-level institutions, and iv) within corporate sector institutions. (p. 186)

However, not all networks result in positive outcomes. Research indicates that networks serve to include some and exclude others, as well as to limit activity that may be beneficial outside the network in order to maintain insider exclusivity. Some organizations, as Kilduff \& Tsai (2003) suggest, "may suffer from a liability of unconnectedness in the sense that organizational members fail to develop strong bonds of trust to important actors inside and outside the organization" (p. 26). A system of inclusion also has wider implications. Research on organizations suggests that when organizations within a field begin to adopt similar mandates, the environment becomes more competitive but not necessarily more effective. Isomorphism is a constraining process that pressures organizations to resemble other organizations. Therefore, as organizations conform to, for example, state and international pressure, the aggregate effect of such individual change is to lessen the extent of diversity within the whole institutional field (DiMaggio \& Powell, 1983, p. 149).

\section{Constructivist Approach to the Institutional Field as the Network Context}

Studies of institution - organization interactions also emphasize the role of relationships in constructing and maintaining institutional structures. An institution is defined by Sipple (1999) as "a socially defined purpose around which normative, cognitive, and regulative structures emerge to provide stability and meaning to social behaviours” (p. 451). These three pillars of institutions (Scott, 2001) function as an institutional field exerting influence on organizations, pressuring them to conform to institutional norms, values, and standards of practice.

According to Scott (2001) institutions are regulative in that they serve to constrain and regularize organizational behaviour through laws, sanctions, and formal regulations. Institutions are normative in that they create social order through prescription, evaluation, and obligation, creating a context where individual and organizational actual behaviour can be compared with preferred behaviour (Sipple, 1999). The cognitive functions of institutions are "based on the notion that individuals [and organizations] interpret and construct their own meaning of the world around them" (Sipple, 1999, p. 453). Davis \& Greve (1997) suggest that

evidence of the legitimacy of an organization's practice differ according to which institutional pillar is examined: conformity to laws and other rules for the regulative pillar, moral endorsement or certification that one meets the obligations of one's role for the normative pillar, and following the prevalent practice in one's field for the cognitive pillar. ( p. 7)

In cases where there are conflicting expectations of organizations embedded in the institutional pillars, how organizations receive, interact with, and internalize 
institutional messages (and pressures) is of particular interest. Understanding how organizations are networked within this field, including both network gaps and connections, has an emancipatory potential in that it can reveal otherwise hidden constraints and opportunities within the patterns of connections. This study revealed four key network gaps that serve as barriers to participation, knowledge and information sharing, and access to resources all necessary in effectively addressing the issues of contemporary child slavery.

\section{Gap 1: Education's Location in Policy Processes}

Education, a key institution of support for children, is significant in that while the education can be a transformative process in both individual lives and in communities, it can also function as a powerful tool of social reproduction. By keeping educators outside current efforts to address child trafficking and child slavery, their potential as agents of change is kept limited and their role, whether intended or unintended, in reproducing the social, economic and political structures that exist continues to be education's main function. Where education mirrors the power structures and forces in society working to perpetuate the structures as they exist, education for children who have been enslaved will exist only to reinforce a permanent inferior economic and social status. Education organizations then, reflect and perpetuate the contradictions of structures of which they are a part and to which they are aligned. However, education organizations can resist these institutional pressures and become powerful locations of social, political and economic change for all society including those most often marginalized. As Brysck (2005) identifies, "norm change is a politics of persuasion, rooted in a dynamic of communicative action” (p. 22) and such change is particularly effective if it addresses the needs of a vulnerable group and is articulated by a group or individual seen as having "moral capital" (Kane, 2001 in Brysck, 2005, p. 22). Educators have both real and perceived expertise in working with children and the potential to present a strong unified moral position on situations of abuse of children therefore holding the potential to act as powerful agents of institutional change.

Three recent policy discussions are helpful in understanding how education organizations are situated in relation to other organizations addressing contemporary child slavery. In 2000, a regional workshop was held in Benin, West Africa (ILO \& IPEC, 2000). This workshop addressed policy and procedures affecting children who were victims of human trafficking and slavery, with the meeting participants arriving at several recommendations regarding future actions. Participants included state officials from West African countries including representatives from women's affairs, youth development, justice, police services as well as several representatives from local, regional and international NGOs. Representatives from the formal school sector were not listed as participants. In the published records of this event, there are two references to education and schools: 1) universal basic education "should be brought to focus on the people, involving NGOs in the implementation" (ILO,

34 Canadian and International Education Vol. 35 no. 1 - June 2006 
2000, Appendix II, Objective 2: Output 2.1) and 2) "Child Rights Clubs should be established in schools and as part of the school curriculum” (ILO, 2000, Appendix II, Objective 2: Output 2.1). In its summary, the document suggests the government should provide funding for free basic education which is also a condition of ILO Convention \#182 ratification.

In another ILO \& IPEC led regional workshop in Asia, efforts were made to address and record how to "create a healing environment" for children who have experienced slavery (ILO \& IPEC, 2002).

Filling the gap between the removal or withdrawal from exploitation and hazardous work situations, including prostitution and sexual exploitation in the workplace, was necessary to ensure that maximum conditions are provided for, for the child to succeed as a learner and as an agent in her or his own development” (p. ii).

Final conclusions from the workshop suggested that there was a need for collaborative efforts between organizations, communities and regions to establish "quality of care standards" (p. 70), perhaps through the creation of multi-disciplinary working groups. This meeting to reformulate approaches to the interventions, rehabilitation and reintegration of children included representatives from local, regional and international NGOs, state officials from departments of health, social services, labour and justice, and international agents (e.g. International Labour Organization officials). Notably absent were representatives of education departments, schools, teachers and other education organizations.

In a report on the "Progress and Future Priorities" of action against child labour, IPEC (2002) leaders stated

There is now a crucial need to enable relevant institutions to support each other and to expand the capacity of partners at all levels. The initiative encourages national institutions to work on particular areas of child labour and then exchange their work through a network. (p. 39)

They report on a successful program in Thailand "Sima Pattana Chivit (Developing Quality of Life) for Girls at Risk of Being Lured into Prostitution” (IPEC, 2002, p. 50). The managers of this project describe the importance of teachers in the success of their program:

The programme identified teachers as key players in implementing the activities. They best know the problems the girls and their families face and can therefore identify girls at risk most effectively. (p. 50)

There is, however, no reference to including teachers in the planning or policy process.

According to UNICEF in extensive field research on child trafficking in Africa, "where large-scale school systems exist, their potential in contributing to the prevention of trafficking has yet to be recognized by the principle agents [stakeholders]” (Unicef, 2003, p. 43).

These reports from recent efforts to address the reintegration needs of children describe the need for collaborative efforts across regions and 
disciplines. "Implementation of policies required effective coordination arrangements, both to achieve an integrated national policy approach and effective mobilization of resources, and to facilitate effective international cooperation” (Unicef, 2003, p. 42). While policy statements indicate the essential nature of education, particularly the provision of free basic education for all children, there are few details of what kind of education should be provided or in what manner. The consultations that preceded the written reports did not include education representatives. This exclusion was confirmed in interviews with staff of organizations working in education provision:

Education is only brought in at the program level, not at the policy level. (Interview, international NGO, 2005)

It comes in at the project level. Not at the level of impact or holding governments responsible. (Interview, community organization, 2004)

not at the level of national action plans. (Interview, international NGO, 2005)

You will see that in general, partners did not place much emphasis on engaging with teachers, perhaps as they are not ILO constituent members, government, employers and trade unions being the tripartite members of the ILO (Interview, International advocacy organization, 2005).

If we are to be effective in addressing the increase in child slavery it requires that these children's needs, and children's needs in general, become more central in local, national and international policy.

Children are used to highlight other things, whether it be the terrible plight of people with AIDS, then children are used as examples, but in terms of entrenching them in the centre of policy, it doesn't happen. (Interview, International NGO, 2005)

Working together has always been important to us and we are trying to document this experience. It is difficult to work together. It can be quite challenging. We are trying to develop our learning around this. One of the main things that we want to get out of the project is that the organizational learning won't be done in isolation. A lot of what we are looking at is to especially look at the gaps, what we are finding is that there are really great and innovative projects out there, but those experiences don't get shared between different organizations, within countries, across countries. These things don't necessarily get recognized and scaled up and replicated in other areas. So that is one thing that we have to take responsibility for and see that that learning gets shared. We need to make changes and do different ways of working. (Interview, donor agency, 2005)

The education sector policy deals with all children and by including this sector as active participants in the policy process, it is more likely that a focus on children will become more than just rhetoric. As the examples here illustrate, there is recognition by those working outside the education sector, that 
educators play an important role in prevention and intervention in child slavery. However, the gap of non-inclusion and nonparticipation, as network research indicates, creates a gap of knowledge and information sharing that makes such interventions and prevention work unlikely. It is important to engage educators in policy dialogues and organizational networks with the intent of creating new forms of education programming that functions as part of a larger interdisciplinary, inter-organizational and international effort to eliminate child slavery.

\section{Gap 2: When is a slave not a slave? Tensions of identity as learner or worker.}

A significant point of tension in interorganizational relationships is the very basic notion of how to speak about children who are slaves. As these quotes highlight, the issue is complex and the positions are polar.

One problem is that the word slavery isn't used... it seems better to use abduction or forced labour. Somehow that makes it easier not to get involved. (Interview, community based organization, 2004)

Of course it's slavery - in its worst forms. There is no doubt that these children were slaves. However, slavery is a very political term. Because slavery is banned, no one wants to call it slavery. The government can't say "we have slavery" to the rest of the world. So we don't use it and you shouldn't either. (Interview, community organization, 2005)

We don't use the term slavery because we understand that term comes with a historical, political context and a historical time period (pause) our organization is leery of using the term slavery outside the historical context of slavery, and particularly talking about slavery in the continent of Africa between African groups transacting children for sale for work (pause) so used in the context of labour, we talk about the worst forms of child labour; in the context of child soldiers, we still put it in the form of worst form of child labour; in the sex trade, we talk about children who are exploited. Because all children [in the sex trade] are exploited; in the context of child trafficking, we talk about children who have been trafficked (Interview, International NGO, 2005)

It is working with reality and real conditions, addressing the reality children will continue to work because of poverty. (Interview, International NGO, 2005)

The norms and understood practice reflected in these statements are significant, particularly in light of the globalization of neoliberal governance and its reform agenda and the primacy of economic development over all matters of social, cultural, or political nature. "Neoliberalism...[is] the belief in the unfettered free market as economically beneficent allied to political ideas stressing the importance of individual freedom and the need to curtail state intervention and interference in individual lives” (Ozga, 2000, p. 59). In this 
neoliberal system, work is considered to be the primary, if not sole, reason for social interaction and education is refocused on creating "workers" (cf . Seddon, Billett \& Clemans, 2004; Ozga, 2000). Dinnerstein (2002) suggests that unemployment is considered a "living death" in the modern world and that work is the organizing principle of society. Therefore, the core understanding of work is that "all work is good" and the tendency is to view work and labour as disconnected from other areas such as poverty or education. When this idea is combined with the focus on individualism, problems related to work exploitation are framed in the individual and local settings, while those structures that create and perpetuate abusive practice remain outside critical examination and policy revision. International financial institutions and state involvement in initiatives such as Structural Adjustment Programs, programs where developing countries are required to downsize their public sectors in exchange for international loans, are downplayed as factors in abusive work practices. These programs designed to create international market friendly environments, have resulted in the collapse of many small, local enterprises that sustained individuals, families, and small communities. It is at this point that the vast increase in slavery is located. "Slavery emerges when economic vulnerability combines with high population growth and a lack of regulation or control over the use of violence” (Bales, 2000, p. 9). Local communities, with economic livelihoods devastated by neoliberal policy and with public sector policy and programming minimized, also according to neoliberal structural adjustment programs, have few material or social resources with which to respond to the new global economic reality into which they are thrust. The whole notion of work shifts in this process. Instead of economic activity supporting the lives of families and local communities, local communities and families become the mechanism to support an economic system where the rewards exist outside their communities (and outside their countries in many cases). Therefore, in the case of children, there is little recognition of the process of identify formation within this narrow understanding of human development and its impact on the present and future agency of the child.

A contrasting position is expressed in the work done by organizations that work directly with children rescued from slavery and use an inclusive rights based citizenship approach. The foundation of this work is that education is a basic human right as identified in the Universal Declaration of Human Rights established by the United Nations in 1948, as well as the Convention on the Rights of the Child, adopted by the General Assembly of the United Nations in November, 1989. The international community has acknowledged education as a human right in ongoing commitments made through the "Education For All" initiatives that began in 1990 at an international gathering and were restated as the Dakar Framework in 2000 and again reframed within the Millennium Development Goals at the UN Millennium Summit in 2000 (cf UNESCO, 2005; 2006). The "Education for All" initiative was to establish universal access to high quality education for all children in the world and despite ample time and 
verbal support, universal education is still a distant dream for many children. Using a rights based approach is a way to disrupt processes of identity construction as a "child worker" that severely limits the possibilities of children who are vulnerable to being exploited in work situations or who have been rescued and are attempting to reenter their communities. The problematic identity involves an understanding that their work is caused by their poverty and there is little choice in their future.

Child labour and poverty can be perceived as the cause of other problems, but I perceive them [differently]; what I have experienced, poverty is not the problem it is the symptom. If the father is unemployed and not been able to get a job naturally the family will remain poor; you can't say it is caused by poverty; it's a question of the father not getting a job. If the people are being underpaid, not paid fairly, they will remain poor; if the family doesn't have enough money then naturally they will turn to their children, send their children to work because children are in demand. (Interview, community based organization, India, 2004)

As well, for this organization, it is important to provide information that supports reconstruction of the identity of educated citizen.

They have the experience but also, the kind of awareness has been put in their mind, you belong to that particular community, so it's your fate... nothing can change, life is like that. And they themselves have had the experience.. no exposure, no education, so naturally they have that mindset. So for them it is an accepted phenomenon. They can't think beyond that. So we have to bring that dream in them. Make them feel like they also are human beings like others, same fundamental rights. [They think] only others have rights, but are not able to speak on it because [they] are not aware of it. So building self-confidence is very important and to make them leaders of their own community, that is the biggest challenge for us".... I ask about education. Is education important? They say no education is not important because so many people don't have jobs so what is the point of us learning? Then I say... what are your "employer's" children doing while you were working? They were going to school Then I say, did he want his children to go to work? They say, no, he wanted them to learn. Then they understand. The employer sends his children to school because he wants them to learn, not because he wants them to be a slave. If you learn things then you might rebel, they always want you to be confined there, you will think it's your fate, that it is your life. (Interview, community based organization, India, 2004)

If education is presented as an alternative and children are assisted in constructing their own identity as that of an educated person, they will choose to go to school rather than work. This runs contrary to the position that children choose not to attend school because of the necessity of work caused by their poverty. Further research in this area is needed if we are to understand fully how 
the identities of poor children are constructed as workers rather than learners. For those who are enslaved in their work, it becomes even more imperative that we understand the cognitive structures within the institutional field that perpetuate their positions, how these structures have been constructed by norms of the neoliberal citizen as worker and enforced through an absence of sanctions and regulations that might provide alternate futures for children abused by slavery.

\section{Gap 3: Donor Influence}

Northern governments are key donors supporting work in the area of child slavery and therefore exert significant influence on the institutional field of education provision.

The[donor] support is there because of target countries and target themes. The decisions are made by Foreign Affairs, by governments whether in Ottawa, Washington or London. At the moment, it happens to be in the interest of international governments to deal with the millennium goals.(Interview, international NGO, 2005).

Although it was also thought that the focus was not on education:

I think that health is more important to donors, like CIDA. They focus on health and not much on education. (Interview, community based organization, 2004).

This was also expressed by other organization staff who experienced a lack of funds because of shifting donor focus. For most, particularly the small, local organizations, this meant the possibility of canceling programs.

Institutions are normative in that they create social order through prescription, evaluation, and obligation, creating a context where individual and organizational actual behaviour can be compared with preferred behaviour (Sipple, 1999). The norms, values, and valued practices of the institutional field exert significant pressure on education organizations. Again, a key normative influence is neo-liberalism. At local, national and international levels a range of actors championing the need for privatization, marketization, performance accountability and rewarding the entrepreneurial individual over the collective, are strongly involved in influencing policy directions that promote a very specific agenda of universal market liberalization (Taylor, Shultz \& Leard, 2005; Ozga, 2000; Gewirtz, Ball \& Bowe, 1995). Northern governments, like Canada, make up some of the strongest supporters of neoliberal policy that promotes a decreased state involvement in service provision while promoting a strong role for governments in creating the economic and social conditions necessary for a strong market environment. According to neoliberal ideology and practice, "a legitimate role for government is to fine-tune and actively promote competition in both the economy and in areas where the market mechanism is traditionally least prone to operate" (Taylor, Shultz \& Leard, 2005, p.257). The effect of these policies and practices serves to inject such market ideas as personal freedom, choice, consumer sovereignty, competition 
and individual initiative, into the political, social and economic activities of the everyday lives of people in all corners of the world. Therefore, in this context, contemporary slavery is viewed as a failure of local policy and particularly as a failure of individual choice. This was evident in a recent discussion with Canadian government policy advisors who suggested that human trafficking and situations of slavery were infrequent, but rather there was an increase of children and families making bad choices regarding the work sites for their children (Personal communication, Government bureaucrat, 2004). From this perspective, donor support is directed at initiatives that provide information and assistance to individual children who are vulnerable or intervention strategies that will interrupt the trafficking or slavery experience. Organizations that aim to provide alternative approaches do not have access to the necessary resources for their work and for engaging in knowledge sharing within the wider network. In effect, they become silenced through organizational disconnection within the institutional field.

\section{Gap 4: The Pull Away from Community}

The current international context is one where the normalizing of global liberalism has shifted normative, regulatory and cognitive practices. In the case of child slavery, there exists an intertwined relationship between global institutions and local abuse by private actors. Brysk (2005) suggests that "liberal globalist visions have concealed important arenas of private power and conflict that must be addressed to secure universal rights” (p. 3). When global links with local sites of struggle are severed, possibilities to interrupt abused become more limited. This issue takes us into the contested areas of the public and also private global civil society involvement in private space, particularly private local space. While the possibilities of transnational hegemony are very real (and well documented) there also exists the reality that transnational efforts might also be the key to the protection of those most vulnerable in local contexts, for example, women and children who are trafficked for slavery. If and how international agents establish and maintain connection to local issues and experience is of critical importance.

Throughout the world, shifting local, national and international relationships have had an impact. States have shifted their policy to be in line with the neoliberal expectations of the international financial system and with this has been the development of systems that allow governments to centralize control and decentralize responsibility or to steer at a distance (Whitty et al., 1998). By using funding and reporting relationships, governments shape, normalize, and instrumentalize conduct, thought, decisions, and aspirations of others in order to achieve their objectives (Miller and Rose, 1990). Organizations are pressured to conform to government policy and institutional pressures through these systems. Often organizations conform without full awareness of the implications. As one education NGO director suggested

It is so easy to be wooed. It is so easy to seduce NGOs with a national consultancy role, or a trip to an international meeting or a little bit of 
money. Soon you realize you have become the middleman between the government and the community. (Interview, community organization, India, 2004)

Programs that had been driven by the needs of the community and often the most marginalized in the community, change and become driven by state or international agendas. One school director working with children removed from slavery lamented the position his organization has come to:

At the moment we have some local NGOs working with them [children returning to the community from slavery] but they are not doing much. And besides they have to ask the national and international NGOs to help. So the local indigenous organizations can't really do much. This is very difficult I tell you! They do their best to go and ask agencies for help to fund our own schools . (Interview, School Director, 2004)

As focus and funds shift away from the local community level so too does knowledge exchange. More and more decisions are made outside local communities. International organizations continue to be the drivers of initiatives rather than the supporters of local efforts.

The power is in the people. There is a power of small organizations linked to the people. It is a problem when people talk about actions without having been there. People who are making statements about what should happen in Sudan or [other places] or with slavery, have never even been there. Never even seen a slave. (Interview, community organization, 2004).

We are all in a way, at the mercy of funding, so the priority countries that are dictated by our respective governments in the alliance are then mentioned in our thematic areas which are priority themes. We are influenced, not necessarily forced, to go in that direction; we are influenced by our government policy. (Interview, International NGO, 2005).

Networks tend to exclude small local organizations whose experience in the face-to-face everyday work with vulnerable and rescued children also is excluded. Networks then serve to increase organizational isomorphism. When organizations within the field begin to adopt similar mandates, the environment becomes more competitive but not necessarily more effective in providing services to the community. This process of isomorphism creates significant changes beyond the individual organizations affecting the whole institutional field. Isomorphism is a constraining process that pressures organizations to resemble other organizations. Therefore, as organizations conform to state and international pressures, the aggregate effect of such individual change is to lessen the extent of diversity within the whole institutional field (DiMaggio \& Powell, 1983, p. 149). As an innovation spreads, a threshold is reached beyond which adoption provides legitimacy rather than improves performance (p. 148). Strategies that are rational for individual organizations may not be rational if adopted by large numbers (p. 148).

42 Canadian and International Education Vol. 35 no. 1 - June 2006 
The processes of exclusion and organizational isomorphism serve to limit the work that is possible in the area of prevention and education provision. The characteristics of contemporary slavery exhibit local and global patterns that require diverse interventions and approaches that reflect the diversity of the local context and the global interconnectedness of the practices and understandings that perpetuate such abuse.

\section{Conclusions}

We need to find ways to be more connected, to present a united front if slavery is to be stopped. (Interview, community organization, 2004)

That is our aim really, with the national organizations. We should try to collaborate and cooperate with organizations. We should try to provide a proper structure of education. (Interview, formal school, 2004).

The organizations within this study all identified collaboration and networking as important to making changes in prevention and intervention strategies for children vulnerable to being enslaved or those rescued from slavery. What the study revealed is that forming effective collaborative networks is difficult and must be addressed in an intentional manner. The issue of transnational, national, and local relations is of particular significance in the issue of contemporary child slavery. We need to support those elements of the public sector and private civil society that work and at the same time provide means for accountability for abuses to be upheld. Shifting the role of education organizations in prevention and intervention related to contemporary slavery would be an effective goal. By recognizing and managing the impact of institutional and organizational networked relations on institutional change, this shift may be possible.

It is important to recognize that networks can also be problematic in their processes of inclusion and exclusion. Work needs to be done to establish appropriate mechanisms to critique whose knowledge is being included and whose is excluded. Small, local organizations and schools that are often excluded, have essential experience and knowledge that must be included, particularly in policy processes. It is also clear that the experiences of children, particularly vulnerable children needs to be brought into the centre of policy and this could be furthered by including educators early in policy processes, by focusing on the experience of children and particularly how they construct identities in relation to the context within which they exist. This will lead to challenges to the norm that poor children have no choice but to work.

Further research is needed to identify ways of managing networks to enhance the benefits and to prevent problems of organizational relationships within institutional contexts. This study also identifies a need for research to understand how best to support efforts to assist children in reconstructing their identities as that of educated citizens rather than slaves. This requires a deeper 
exploration of the intersections of poverty, the universal right to education and child workers.

\section{References:}

Atkinson, R., Flint, J. (2001). Accessing hidden and hard to reach participants. Social research update. Issue 33. Surrey, UK: University of Surrey

Bales, K. (1999). Disposable People: New Slavery in the Global Economy. Berkeley/London: University of California Press

Bales, K. (2000). Slavery in the Age of Globalization, Journal of International Affairs, 53 (2), 461-484

Bales, K., Fletcher, L. \& Stover, E. (2004). Hidden Slaves: Forced Labour in the US.Report for Free the Slaves, Washington, DC \& Human Rights Centre, University of California, Berkeley, CAL.

Brysk, A. (2005). Human Rights and Private Wrongs. Constructing Global Civil Society. New York/London: Routledge

Church, M., Bite, M., Armstrong , K. \& Fernando, P. et al (2002). Participation, Relationships and Dynamic Change: New Thinking on Evaluating the Work of International Networks. Working paper No. 121. London: Development Planning Unit, University College London.

Davis, R. (2003). Network Perspectives in the Evaluation of Development Interventions: More than a Metaphor. Paper presented at EDAIS Conference, November 2425, 2003.

Davis,G. \& Greve, H. (1997). Corporate Elite Networks and Governance Changes in the 1980s. American Journal of Sociology. 103 (1), 1-37.

DiMaggio, P. \& Powell,W. (1983). The Iron Cage Revisited: Institutional Isomorphism and Collective Rationality in Organizational Fields. American Sociological Review. 48 (April), 147-160.

Dinerstein, A.C. \& Neary, M. (2002). From Here to Utopia: Finding Inspiration for the Labour Debate. In Dinerstein, A.C. \& Neary, M. (Eds.). The Labour Debate: An Investigation into the Theory and Reality of Capitalist Work. Aldershot, UK: Ashgate. pp. 1-26.

Farquharson, K. (2003). A different kind of snowball: Identifying key policymakers. International journal of social research methodology. 8 (4) 345- 353.

Gewirtz, S., Ball,S. and Bowe, R. (1995). Markets, Choice and Equity in Education. Buckingham: Open University Press.

International Labour Organization (ILO) (2002a). A Future Without Child Labour: Global Report under the Follow-up to the ILO Declaration on Fundamental Principles and Rights at Work. Geneva: ILO.

ILO (2002b). Eliminating the Worst Forms of Child Labour: A Practical Guide to ILO Convention No. 182. Geneva: ILO.

ILO (2002c). Unbearable to the human heart. Child trafficking and action to eliminate it. Geneva: ILO.

ILO \& International Programme on the Elimination of Child Labour. (2000). Combating Trafficking in Children for Labour Exploitation in West and Central Africa. Report on Sub-Regional Workshop. Cotonou, Benin.

IPEC) ILO (2002). Creating aHealing Environment. Psycho-Social Rehabilitation and Occupational Integration of Child Survivors of Trafficking and Other Worst

44 Canadian and International Education Vol. 35 no. 1 - June 2006 
Forms of Child Labour. Proceedings from Trafficking in Children-South Asia Conference, Katmandu, Nepal.

Kilduff, M. \& Tsai, W. (2003). Social Networks and Organizations. London: Sage Publishers.

Ozga, J. (2000). The Context of Policy Research. In Policy Research in Educational Settings: contested terrain. Buckingham and Philadelphia: Open University Press, pp. 56-67.

Scott, R. (1998). Organizations: Rational, Natural and Open Systems. Upper Saddle River, N.J.: Prentice Hall.

Seddon, T. Billett, S., Clemans, A. (2004). Politics of social partnerships: a framework for theorizing. Journal of education policy. 19 (2) 124-144.

Sipple, J. (1999). Institutional constraints on business involvement in K-12 Education Policy. American Education Research Journal. Fall, 36 (3), 447-488.

Taylor, A., Shultz, L., \& Wishart Leard, D. (2005). A new regime of accountability in Alberta schools. In T. Harrison (Ed.), The Trojan horse rides again: Alberta, Canada, and the new world (dis)order. Montreal: Black Rose Books.

UN (United Nations) (2000). Protocol to Prevent, Suppress and Punish Trafficking in Persons, Especially Women and Children, Supplementing the United Nations Convention Against Transnational Organized Crime. New York: United Nations.

UN DESA (United National Division for the Advancement of Women, Department of Economic \& Social Affairs) (2002). The UN Response to trafficking in Women and girls. New York: United Nations

UNESCO (2005). Education for all: The quality imperative. EFA Global Monitoring Report. Paris: UNESCO.

UNESCO (2006). Literacy for life. EFA Global Monitoring Report. Paris: UNESCO.

UNICEF (2003). Trafficking in Human Beings, Especially Women and Children, in Africa. Unicef Innocenti Research Centre: Florence, Italy.

Van Meter, M. (1990). Methodological and design issues. NIDA Research Monograph, pp. 31-43.

Vogt, W. (1999). Dictionary of statistics and methodology. London: Sage

Whitty, J., Halpin, D., and Power, S. (1998). Devolution and choice in education. Buckingham: Open University Press.

Woolcock, M. (1998). Social capital and economic development: Toward a theoretical synthesis and policy framework. Theory and Society. 27, 151-208.

Lynette Shultz (lshultz@ualberta.ca) is a PhD Candidate in Educational Policy Studies at the University of Alberta. She is Director of the EDPS Global Education Network and currently researches in the areas of children and work with a particular focus on contemporary child slavery, educating for human rights, and organizing formal and nonformal education for social justice. 